\title{
Italy: Financial Sector Assessment Program- Detailed Assessment of Observance of the IMF Code of Good Practices on Transparency in Monetary and Financial Policies-Securities Regulation
}

This Detailed Assessment of Observance of the IMF Code of Good Practices on Transparency in Monetary and Financial Policies - Securities Regulation for Italy was prepared by a staff team of the International Monetary Fund as background documentation to the Financial Sector Assessment Program with the member country. It is based on the information available at the time it was completed in February 2006. The views expressed in this document are those of the staff team and do not necessarily reflect the views of the government of Italy or the Executive Board of the IMF.

The policy of publication of staff reports and other documents by the IMF allows for the deletion of market-sensitive information.

To assist the IMF in evaluating the publication policy, reader comments are invited and may be sent by e-mail to publicationpolicy@imf.org.

Copies of this report are available to the public from

International Monetary Fund $\bullet$ Publication Services

700 19th Street, N.W. • Washington, D.C. 20431

Telephone: (202) $6237430 \bullet$ Telefax: (202) 6237201

E-mail: publications@imf.org • Internet: http://www.imf.org

Price: $\$ 15.00$ a copy

\section{International Monetary Fund}

Washington, D.C. 



\title{
FinANCIAL SECTOR ASSESSMENT PROGRAM
}

\author{
DETAILED ASSESSMENT OF OBSERVANCE OF THE IMF CODE OF \\ GOOD PraCtices ON TRANSPARENCY IN MONETARY AND \\ FinANCIAL POLICIES-SECURITIES REgUlation
}

\section{ITALY}

FEBRUARY 2006 


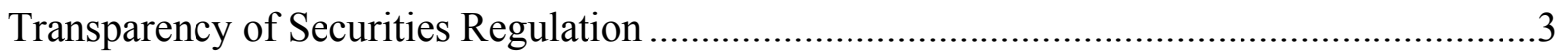

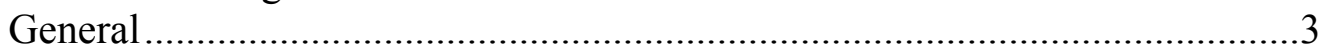

Practice-by-practice assessment.......................................................

Tables

1. Practice-by-Practice Assessment of Observance of IMF's MFP Transparency Code Practices - Securities Regulation ..........................................................................4

2. Recommended Plan of Actions to Improve Observance of IMF's MFP Transparency

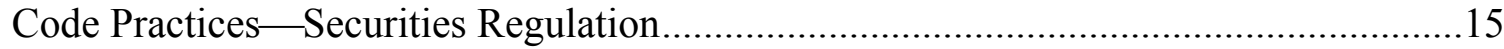




\section{Transparency OF SECURITIES REgUlation}

\section{General}

1. This assessment of Italy's compliance with the IMF's Transparency Code for Securities Regulation was carried out in the context of the FSAP for Italy. The evaluation is based on the self assessments provided by the Consob and BI regarding their respective roles in securities regulation and supervision, discussions with senior staff of both institutions, as well as legal sources, including the Consolidated Law on Financial Intermediation. ${ }^{1}$ The assessment was based on the MFPT Code, and has taken into account the implementation issues mentioned in the Supporting Document to the MFPT Code.

2. The Italian authorities cooperated fully with the assessment and provided the necessary information and documentation requested by the mission.

\section{Institutional and market structure overview}

3. In the area of securities regulation, the objectives and responsibilities of the two supervisory authorities, namely Consob and the BI, and the modalities of cooperation between them, are clearly established in the 1998 Consolidated Law. An area where further clarity may be warranted concerns the practical modalities of exchanging information with other domestic institutions. The regulatory framework is publicly disclosed and explained, through the two institutions' comprehensive publications program, a multi-faceted communication strategy including educational efforts and officials' public speeches, and a presumption in favor of consulting securities market participants. Regular reporting and testimony before the Ministry of Economy and Finance and/or Parliament also upholds accountability in this policy area, while internal governance arrangements, audited financial statements and rules on staff conduct provide further assurances of integrity.

\section{Practice-by-practice assessment}

4. The assessment of observance with each practice of the MFPT Code is made qualitatively, based on existing laws, regulations, and practices. A five-part assessment system is used: observed, implying full observance or with insignificant shortcomings; broadly observed, where weaknesses might exist but these are not seen as being of a significant nature so as to raise serious doubts about the BI's ability to achieve the objective of that practice; partly observed, where shortcomings are sufficient to raise doubts about the BI's ability to achieve observance and could affect policy effectiveness; not observed, where the practice is not being observed and no substantive progress has been recorded toward

\footnotetext{
1 The mission took place in November 2004; the assessment was carried out by José Manuel Portero and Laurent Bouscharain (respectively from the Spanish CNMV and the IMF)
} 
achieving the objectives of the practice; and not applicable, where, due to the institutional and legal framework, the transparency practice is not relevant.

Table 1. Practice-by-Practice Assessment of Observance of IMF's MFP Transparency Code Practices-Securities Regulation

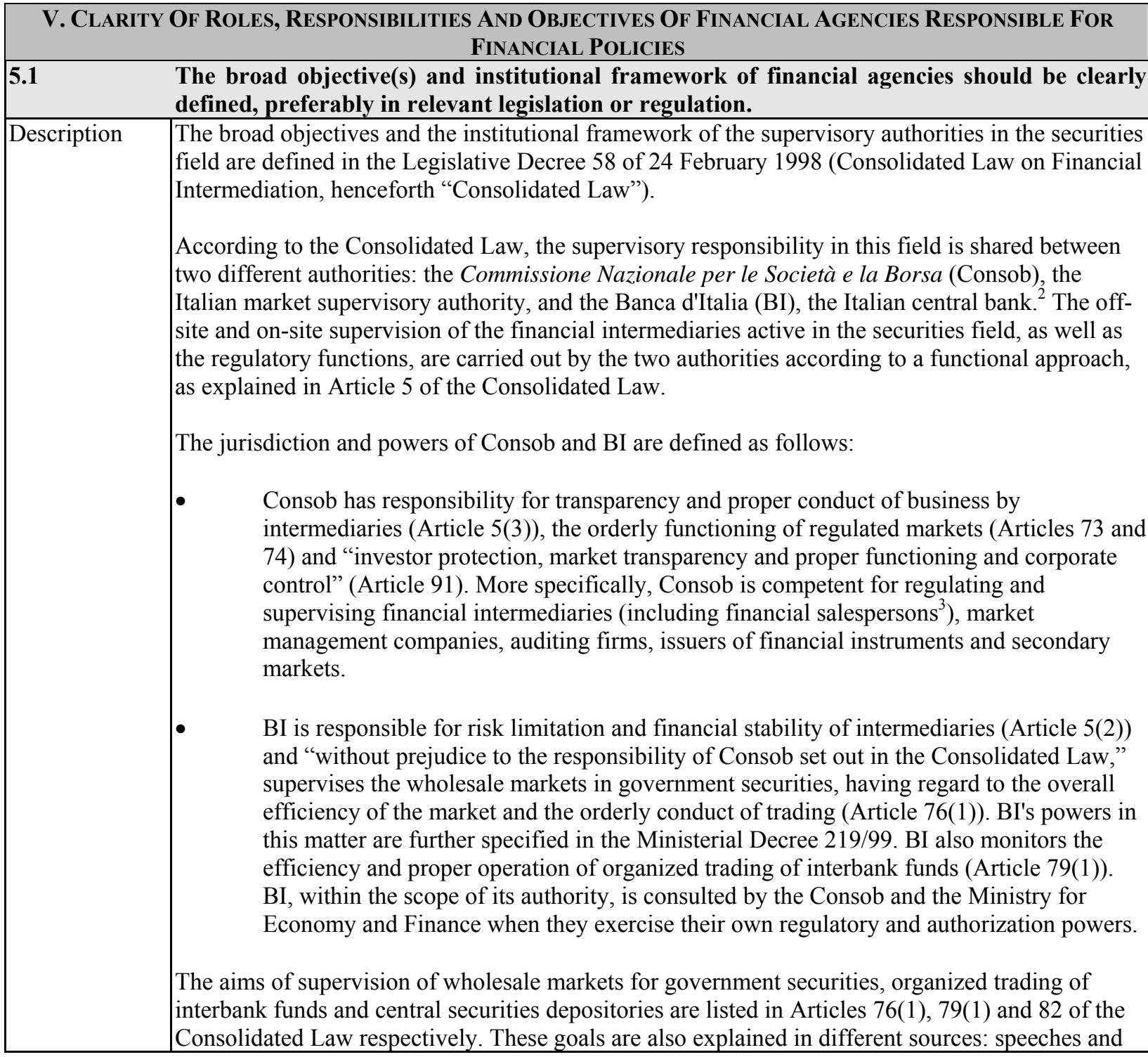

\footnotetext{
${ }^{2}$ For the purpose of this document the expressions "Banca d'Italia" and "BI" refer to the Bank in its capacity of supervisory authority in the securities field.

${ }^{3}$ A financial salesperson is any natural person who, as employee, agent or mandatory, performs door-to-door selling on a professional basis on behalf of an authorized intermediary.
} 


\begin{tabular}{|c|c|}
\hline & $\begin{array}{l}\text { appearances by officials of BI, official publications and commentaries to the Consolidated Law. } \\
\text { The Consolidated Law provides that Consob and BI, in the areas of shared jurisdiction, must co- } \\
\text { operate, including with a view to minimizing the costs imposed on supervised entities. It also states } \\
\text { that the supervisory authorities may not invoke professional secrecy in their mutual relations. }\end{array}$ \\
\hline Assessment & Observed \\
\hline 5.1 .1 & The broad objective(s) of financial agencies should be publicly disclosed and explained. \\
\hline Description & $\begin{array}{l}\text { As explained above in 5.1, the broad objectives of Consob and BI are defined by the Consolidated } \\
\text { Law. }\end{array}$ \\
\hline Assessment & Observed \\
\hline 5.1 .2 & $\begin{array}{l}\text { The responsibilities of the financial agencies and the authority to conduct financial policies should } \\
\text { be publicly disclosed. }\end{array}$ \\
\hline Description & $\begin{array}{l}\text { The jurisdiction, responsibilities and powers of Consob are set out in statutory provisions. The } \\
\text { main provisions governing Consob are set out in Law 216/1974 (as amended) and in the } \\
\text { Consolidated Law. Consob has responsibility for transparency and proper conduct of business by } \\
\text { intermediaries (Article 5(3)), the orderly functioning of regulated markets (Article } 73 \text { and } 74 \text { ) and } \\
\text { "investor protection, transparency and proper functioning of markets and corporate control" } \\
\text { (Article 91). } \\
\text { The jurisdiction and responsibilities of BI are publicly disclosed in different legal sources: the } \\
\text { bylaws of BI (ratified by Decree no.1067/1936, as amended) and the banking and financial } \\
\text { legislation (Legislative Decree no.385/1993, hereinafter "Consolidated Law on Banking;" and the } \\
\text { Consolidated Law). }\end{array}$ \\
\hline Assessment & Observed \\
\hline 5.1 .3 & $\begin{array}{l}\text { Where applicable, the broad modalities of accountability for financial agencies should be publicly } \\
\text { disclosed. }\end{array}$ \\
\hline Description & $\begin{array}{l}\text { According to Article } 1(13) \text { of Law } 216 / 1974 \text {, Consob must submit a report at least once a year to } \\
\text { the MoF which, in turn, must present it (with any comments) to Parliament. The annual report must } \\
\text { lay out the activities performed by Consob and indicate policy orientations for the following year. } \\
\text { The annual report of Consob in Italian and an abridged English version are posted on the Consob's } \\
\text { Web site. } \\
\text { Moreover, once a year, the Chairman of Consob officially presents the activity of the Commission } \\
\text { to market participants. The document submitted on that occasion summarizes current activities and } \\
\text { highlights prospects. } \\
\text { The Chairman of Consob is required to keep the MoF informed about major developments on the } \\
\text { markets and the operation of the Commission (see Article 1(12) of Law 216/74). The Minister is } \\
\text { entitled to communicate his views to the Commission, informing Parliament at the same time about } \\
\text { these initiatives and their content. More generally, the Minister of Economy and Finance can } \\
\text { comment at any time to Parliament on the activities of Consob. } \\
\text { The Parliament and parliamentary commissions are entitled to call the Chairman of Consob or the } \\
\text { other Consob Commissioners for special hearings. } \\
\text { BI publicly reports on issues within the scope of its authority through its annual report or through } \\
\text { parliamentary hearings whenever the Parliament requires technical advice on subjects related to the } \\
\text { functions of the Bank of Italy and on other occasions. Testimonies before Parliament are generally } \\
\text { made by the Governor, the Director General and the Deputies of the Director General, and } \\
\text { occasionally by other senior BI officials. The annual report of BI in Italian and an abridged English } \\
\text { version are posted on the BI Web site. } \\
\text { During general shareholder meetings, to be held no later than } 31 \text { May each year, the concluding }\end{array}$ \\
\hline
\end{tabular}




\begin{tabular}{|c|c|}
\hline & arks of the Governor include an analysis of financial markets and intermediation. \\
\hline Assessment & Observed \\
\hline 5.1 .4 & $\begin{array}{l}\text { Where applicable, the procedures for appointment, terms of office, and any general criteria for } \\
\text { removal of the heads and members of the governing bodies of financial agencies should be } \\
\text { publicly disclosed. }\end{array}$ \\
\hline Description & 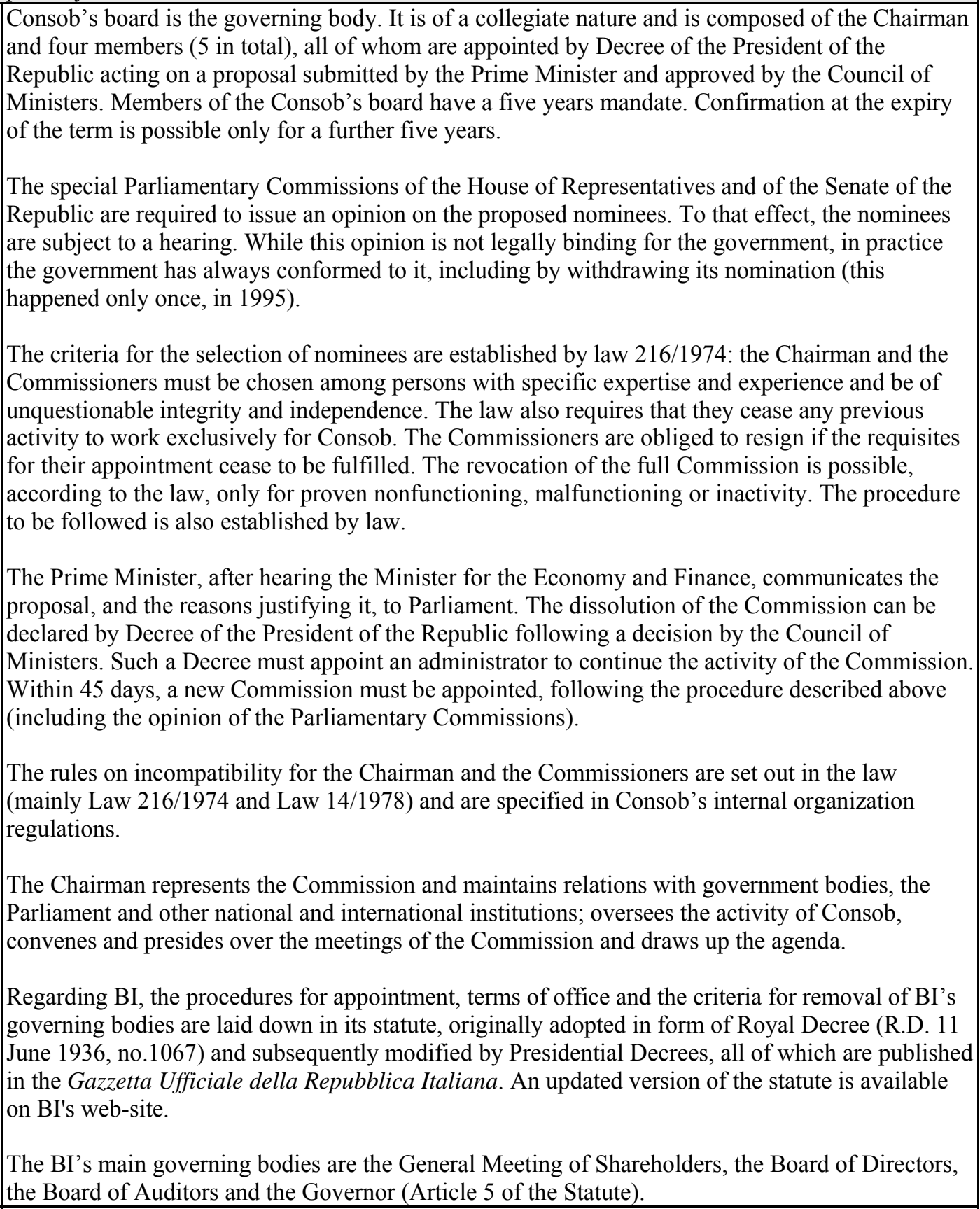 \\
\hline Assessment & Broadly Observed \\
\hline Comment & $\begin{array}{l}\text { While Practice 5.1.4 "is fully observed as far as Consob is concerned, there is lack of clarity as far } \\
\text { as the criteria for dismissal of the Governor and the Board of Directors of thefor BI. The recently }\end{array}$ \\
\hline
\end{tabular}




\begin{tabular}{|c|c|}
\hline & $\begin{array}{l}\text { adopted Savings Law explicitly mentions Article } 14.2 \text { of the ESCB Statute for the Governor's } \\
\text { dismissal procedures. }\end{array}$ \\
\hline 5.2 & The relationship between financial agencies should be publicly disclosed. \\
\hline Description & $\begin{array}{l}\text { As explained in Practice 5.1, the Consolidated Law defines the respective responsibilities of } \\
\text { Consob and BI regarding securities markets regulation. } \\
\text { Moreover, Article 4(1) of the Consolidated Law provides that Consob, BI, ISVAP (the insurance } \\
\text { regulator), the UIC (anti-money laundering authority) and COVIP (the pension regulator) must } \\
\text { cooperate by exchanging information or otherwise for the purposes of facilitating their respective } \\
\text { functions. In particular, Article 5(4) of the Consolidated Law requires that BI and Consob operate } \\
\text { in a coordinated manner with a view to minimizing the costs imposed on supervised entities, } \\
\text { notifying each other of the measures adopted and the irregularities discovered in carrying out } \\
\text { respective supervisory activities. Pursuant to Article } 10 \text { of the Consolidated Law, BI and Consob, } \\
\text { in exercising their respective powers to inspect intermediaries that provide investment and } \\
\text { collective asset management services, must notify each other of such inspections. Each authority } \\
\text { can satisfy its informational needs by requesting the other to carry out on-site inspections. }\end{array}$ \\
\hline Assessment & Observed \\
\hline 5.3 & The role of oversight agencies with regard to payment systems should be publicly disclosed. \\
\hline Description & As securities regulators, Consob and BI have no responsibility in the area of payment systems. \\
\hline Assessment & Non applicable \\
\hline 5.3 .1 & $\begin{array}{l}\text { The agencies overseeing the payment system should promote the timely public disclosure of } \\
\text { general policy principles (including risk management policies) that affect the robustness of } \\
\text { systemically important payment systems. }\end{array}$ \\
\hline Description & See 5.3 \\
\hline Assessment & Non applicable \\
\hline 5.4 & $\begin{array}{l}\text { Where financial agencies have oversight responsibilities for self-regulatory organizations } \\
\text { (e.g., payment systems), the relationship between them should be publicly disclosed. }\end{array}$ \\
\hline Description & Self regulation is non existent in Italy to date. \\
\hline Assessment & Non applicable \\
\hline 5.5 & $\begin{array}{l}\text { Where self-regulatory organizations are authorized to perform part of the regulatory and } \\
\text { supervisory process, they should be guided by the same good transparency practices specified } \\
\text { for financial agencies. }\end{array}$ \\
\hline Description & See 5.4 \\
\hline Assessment & Non applicable \\
\hline \multicolumn{2}{|r|}{ VI. OPEN Process For Formulating AND REPORTING OF FINANCIAL POLICIES } \\
\hline 6.1 & $\begin{array}{l}\text { The conduct of policies by financial agencies should be transparent, compatible with } \\
\text { confidentiality considerations and the need to preserve the effectiveness of actions by } \\
\text { regulatory and oversight agencies. }\end{array}$ \\
\hline Description & $\begin{array}{l}\text { All the rules and regulations issued by Consob and those governing the operation of Consob are } \\
\text { published in Consob's Official Journal (regulations are also published in the Official Journal - } \\
\text { Gazzetta Ufficiale della Repubblica) and on Consob's Web site, and are therefore available to the } \\
\text { public. The main regulations implementing the Consolidated Law are also available in English. } \\
\begin{array}{l}\text { According to Article } 4(2) \text { of the Consolidated Law on banking, BI establishes and gives prior } \\
\text { public notice of the principles and methods used under its supervisory activity and publish an } \\
\text { annual report on such activity. This report includes an extensive section on developments in the } \\
\text { regulation and structure of the Italian financial system, the risks, profitability and capital adequacy } \\
\text { of intermediaries, and inspections carried out in the course of supervisory activity. }\end{array}\end{array}$ \\
\hline Assessment & Broadly Observed \\
\hline Comments & $\begin{array}{l}\text { The transparency of exchange of information and consultation between financial agencies could be } \\
\text { improved. While the law requires Italian financial agencies to cooperate and broadly defines the } \\
\text { objectives of their cooperation, the protocols that define the practical modalities of their }\end{array}$ \\
\hline
\end{tabular}




\begin{tabular}{|c|c|}
\hline & $\begin{array}{l}\text { cooperation and information sharing procedures are not made public. } \\
\text { The Italian authorities intend to do so following the completion of the ongoing revision of the } \\
\text { protocol. }\end{array}$ \\
\hline 6.1 .1 & $\begin{array}{l}\text { The regulatory framework and operating procedures governing the conduct of financial policies } \\
\text { should be publicly disclosed and explained. }\end{array}$ \\
\hline Description & $\begin{array}{l}\text { As explained in 6.1, the principles and methods guiding Consob's and BI's supervisory activities } \\
\text { are published in their regular publications and are made available on the internet. }\end{array}$ \\
\hline Assessment & Observed \\
\hline 6.1 .2 & $\begin{array}{l}\text { The regulations for financial reporting by financial institutions to financial agencies should be } \\
\text { publicly disclosed. }\end{array}$ \\
\hline Description & $\begin{array}{l}\text { Reporting requirements to Consob by financial intermediaries are established and explained in } \\
\text { detail in Regulation no.15222/1998 and Resolution no.14015/2003. } \\
\text { The Consolidated Law and the Consolidated Law on Banking define the modalities of data and } \\
\text { other information collection by BI. The procedures for completing statistical reports are provided } \\
\text { to each supervised institution and are available on BI's Web site. Manuals explaining the data } \\
\text { which must be reported to BI and the methods used to compile them are also published. }\end{array}$ \\
\hline Assessment & Observed \\
\hline 6.1 .3 & $\begin{array}{l}\text { The regulations for the operation of organized financial markets (including those for issuers of } \\
\text { traded financial instruments) should be publicly disclosed. }\end{array}$ \\
\hline Description & $\begin{array}{l}\text { Regulations for the operation of organized financial markets are laid down in Regulation } \\
\text { no.11768/1998 and implementing resolutions. Issuers are regulated by Regulation no.11971/1999. }\end{array}$ \\
\hline Assessment & Observed \\
\hline 6.1 .4 & $\begin{array}{l}\text { Where financial agencies charge fees to financial institutions, the structure of such fees should be } \\
\text { publicly disclosed. }\end{array}$ \\
\hline Description & $\begin{array}{l}\text { Since } 1995 \text { (Article } 40 \text { of Law 724/1994) Consob has been funded partly through a specific } \\
\text { allocation from the central government budget and partly through fees collected directly from } \\
\text { markets and market participants for the activities performed. Before } 1995 \text { Consob was entirely } \\
\text { funded from the State budget. } \\
\text { By July } 31 \text { st of each year, Consob informs the MoF about its projected revenues and funding needs } \\
\text { for the following year. On the basis of this information the MoF sets the annual allocation from the } \\
\text { State budget. } \\
\text { Consob fixes the types and amounts of fees in resolutions rendered effective by a decree signed by } \\
\text { the Prime Minister after checking their legitimacy and consulting the MoF. } \\
\text { The fee schedule for the } 2004 \text { financial year is set out in Resolutions } 14376 \text { and } 14377 \text { of } 30 \\
\text { December } 2003 \text {. In addition, Resolution } 14381 \text { of } 12 \text { January } 2004 \text { lays down the time limits and } \\
\text { procedures for the payment of fees. The text of the above-mentioned resolutions is available on } \\
\text { Consob's Web site and on Consob's Official Journal. } \\
\text { As a government securities regulator, BI doesn't charge any fee to financial institutions. }\end{array}$ \\
\hline Assessment & Observed \\
\hline 6.1 .5 & $\begin{array}{l}\text { Where applicable, formal procedures for information sharing and consultation between financial } \\
\text { agencies (including central banks), domestic and international should be publicly disclosed. }\end{array}$ \\
\hline Description & $\begin{array}{l}\text { As explained above, Italian supervisory authorities are obliged by law to cooperate. Pursuant to } \\
\text { Articles } 4(2) \text { and } 4(3) \text { of the Consolidated Law, Consob and BI may exchange confidential } \\
\text { information held in their archives or provide information to a foreign regulator. }\end{array}$ \\
\hline
\end{tabular}




\begin{tabular}{|c|c|}
\hline & $\begin{array}{l}\text { Consob has signed several international MOUs like the IOSCO MOU, the CESR }{ }^{4} \mathrm{MOU} \text {, and } \\
\text { bilateral MOUs. }\end{array}$ \\
\hline Assessment & Partially Observed \\
\hline Comments & $\begin{array}{l}\text { While international MOUs are made public, the protocols which define the modalities of the } \\
\text { cooperation and the extent of information sharing between Italian regulators have not been made } \\
\text { public. } \\
\text { Subsequent to the assessment, the MOU governing the cooperation and exchange of information } \\
\text { between BI and Consob was made public on the Web sites of the two institutions. }\end{array}$ \\
\hline 6.2 & $\begin{array}{l}\text { Significant changes in financial policies should be publicly announced and explained in a } \\
\text { timely manner. }\end{array}$ \\
\hline Description & $\begin{array}{l}\text { Consob publishes a weekly newsletter (available in English) summarizing the main activities and } \\
\text { decisions taken during the week and calling for responses to consultation as may be the case with } \\
\text { respect to the introduction of significant changes in policies or new regulations. } \\
\text { The adoption of significant regulations and regulatory changes, including those affecting the } \\
\text { securities markets falling under the jurisdiction of BI, is normally discussed in advance with } \\
\text { interested parties. The issuance of regulations (including subsequent changes) is also announced } \\
\text { and explained through public releases to the media and communications to supervised entities. BI } \\
\text { also communicates to the system interpretative recommendations, guidance or instructions for the } \\
\text { application of the regulations falling under its jurisdiction. Clarifications on technical issues are } \\
\text { also provided by senior officials participating in seminars, conferences, meeting with market } \\
\text { participants, etc. The BI's annual report also includes the description of supervisory activities on } \\
\text { market infrastructures (see also 6.1). }\end{array}$ \\
\hline Assessment & Observed \\
\hline 6.3 & $\begin{array}{l}\text { Financial agencies should issue periodic public reports on how their overall policy objectives } \\
\text { are being pursued. }\end{array}$ \\
\hline Description & $\begin{array}{l}\text { In accordance with Article } 1(13) \text { of Law } 216 / 1974 \text {, Consob must submit a report at least once a } \\
\text { year to the Minister for the Economy and Finance who, in turn, is requested to present it (with any } \\
\text { comments) to the Parliament. The annual report should explain the activities performed by Consob } \\
\text { and indicate policy orientations for the following year. } \\
\text { Moreover, once a year, the Chairman of Consob presents the activity of the Commission to market } \\
\text { participants in an official ceremony. The document submitted on that occasion discusses present } \\
\text { activities and prospects. } \\
\text { BI reports in the sections of the annual report devoted to the supervisory activities on } \\
\text { intermediaries and wholesale markets of government securities, explaining inter alia the modalities } \\
\text { through which policy objectives are being pursued. }\end{array}$ \\
\hline Assessment & Observed \\
\hline 6.4 & $\begin{array}{l}\text { For proposed substantive technical changes to the structure of financial regulations, there } \\
\text { should be a presumption in favor of public consultations, within an appropriate period. }\end{array}$ \\
\hline Description & $\begin{array}{l}\text { Before adopting any new regulations or making any policy change, Consob consults with market } \\
\text { participants and concerned entities. New draft regulations are published on Consob's Web site. } \\
\text { As member of the CESR (Committee of European Securities Regulators), Consob also organizes } \\
\text { consultation on CESR's documents and standards before their adoption, including the "Technical }\end{array}$ \\
\hline
\end{tabular}

\footnotetext{
${ }^{4}$ CESR stands for Committee of European Securities Regulators.
} 


\begin{tabular}{|c|c|}
\hline & $\begin{array}{l}\text { Advices" to be forwarded to the European Commission in view of the adoption of European } \\
\text { Directives and Regulations implementing Directives of the European Council and Parliament. } \\
\text { Although there is no legal obligation to undertake public consultations, it is a common practice for } \\
\text { BI to consult with the market, to discuss major changes of the regulation falling under its } \\
\text { jurisdiction. Those consultations normally involve the relevant associations representing interested } \\
\text { parties but also, if deemed necessary, external experts (such as academics). Such consultations may } \\
\text { consist in an open period for submission of written comments or in meetings with the most } \\
\text { interested parties. } \\
\text { Such practice has proved particularly useful for the drafting of the Consolidated Law and of the } \\
\text { relevant implementing measures. }\end{array}$ \\
\hline Assessment & Observed \\
\hline & VII. Public AVAILABILITy Of Information ON Financial POLICIES \\
\hline 7.1 & $\begin{array}{l}\text { Financial agencies should issue a periodic public report on the major developments of the } \\
\text { sector(s) of the financial system for which they carry designated responsibility. }\end{array}$ \\
\hline Description & $\begin{array}{l}\text { Both the Consob and the BI publish regular reports on major developments in the securities market } \\
\text { that are available on their Web sites. } \\
\text { Moreover, weekly notes for Consob and the Monthly Bulletin of the BI complement annual } \\
\text { publications with more frequent information }\end{array}$ \\
\hline Assessment & Observed \\
\hline 7.2 & $\begin{array}{l}\text { Financial agencies should seek to ensure that, consistent with confidentiality requirements, } \\
\text { there is public reporting of aggregate data related to their jurisdictional responsibilities on a } \\
\text { timely and regular basis. }\end{array}$ \\
\hline Description & $\begin{array}{l}\text { Data are published on the Web site, in the annual report and in other documents issued by Consob. } \\
\text { Consob publishes on its Web site information on the persons holding significant shares in the } \\
\text { capital of listed Italian companies (i.e., } 2 \text { percent and above). For the sake of market transparency, } \\
\text { the information is not published in aggregate form, but provides the names of the shareholders (or } \\
\text { participants in shareholders agreements). } \\
\text { BI also maintains an extensive database created on the information concerning the activity of } \\
\text { market operators of wholesale markets for government securities and management companies in } \\
\text { the field of post trading. Some aggregate data are also disseminated through BI's annual report, the } \\
\text { Economic and Statistical Bulletin, and its supplements. }\end{array}$ \\
\hline Assessment & Observed \\
\hline 7.3 & $\begin{array}{l}\text { Where applicable, financial agencies should publicly disclose their balance sheets on a pre- } \\
\text { announced schedule, and after a predetermined interval, publicly disclose information on } \\
\text { aggregate market transactions. }\end{array}$ \\
\hline Description & $\begin{array}{l}\text { The budget and the financial statements of Consob, which provide detailed information on the use } \\
\text { of its resources, are made available to the public on Consob's Web site and Official Journal. } \\
\text { BI does not prepare disaggregated financial accounts for its function as a securities regulator. BI } \\
\text { publishes its aggregate balance sheet in the Annual Report. }\end{array}$ \\
\hline Assessment & Observed \\
\hline 7.3 .1 & $\begin{array}{l}\text { Consistent with confidentiality and privacy of information on individual firms, aggregate } \\
\text { information on emergency financial support by financial agencies should be publicly disclosed } \\
\text { through an appropriate statement when such disclosure will not be disruptive to financial stability. }\end{array}$ \\
\hline Description & As securities market regulators, Consob and BI cannot provide emergency financial support. \\
\hline Assessment & Not applicable \\
\hline 7.4 & Financial agencies should establish and maintain public information services. \\
\hline Description & $\begin{array}{l}\text { Consob has set up a special unit for Relations with the Public in charge of responding to requests } \\
\text { for information received from investors. } \\
\text { Moreover, for some time now, Consob's strategic objectives have included investor education, to }\end{array}$ \\
\hline
\end{tabular}




\begin{tabular}{|c|c|}
\hline & $\begin{array}{l}\text { enhance investors' ability to protect themselves, which is a necessary complement to the traditional } \\
\text { supervisory tasks assigned by law for the protection of investors. A special section of Consob's } \\
\text { web site is devoted to investor protection. The first section of the site is the "Investors' corner," } \\
\text { which includes subsections devoted to "Dos and Don'ts" and investor education initiatives. } \\
\text { Moreover, it has a "Warnings section" to notify investors about entities providing unauthorized and } \\
\text { fraudulent investment services. Special icons give access to the most recent issues of the weekly } \\
\text { newsletter and of Consob's Official Journal, press releases and the ownership structure of listed } \\
\text { companies. With respect to complex financial products (such as "covered warrants" and "reverse } \\
\text { convertible bonds") Consob's Web site provides tools to help investors assess the risks associated } \\
\text { with such products. } \\
\text { The list of persons authorized to offer investment services and of tender offers is also published on } \\
\text { Consob's Web site. Besides summarizing the main features of the transaction (type of offer, issuer, } \\
\text { offeror, offer period), the Web site allows users to view or download the offer document (for } \\
\text { transactions dating from 9 May } 2000 \text { onward). } \\
\text { Consob has been involved in "The Law on the web" project of the Authority for IT in the Public } \\
\text { Administration and was one of the first authorities to apply the standards for structuring and } \\
\text { marking legal documentation, permitting users of the legal portal www.normeinrete.it to consult } \\
\text { the "Legal framework" ("Regolamento") section of its own Web site. } \\
\text { BI also has a structured public information system to disseminate statistics and data, economic } \\
\text { bulletins and papers, legal publications, supervision rules, lists of authorized intermediaries, its } \\
\text { annual report, regional economic reports, speeches of senior officials and the texts of key } \\
\text { testimony given to Parliamentary committees, and press releases by the Communication and Press } \\
\text { Relations Division. }\end{array}$ \\
\hline Assess & Observed \\
\hline 7.4 .1 & $\begin{array}{l}\text { Financial agencies should have a publications program, including a periodic public report on their } \\
\text { principal activities issued at least annually. }\end{array}$ \\
\hline Description & $\begin{array}{l}\text { All the decisions taken by Consob during the week are published on Friday in Consob's newsletter } \\
\text { (available in English on Consob's web site). All the rules and regulations issued by Consob are } \\
\text { published in Consob's Official Journal (regulations are also published in the Official Journal - } \\
\text { Gazzetta Ufficiale della Repubblica) - and on Consob's Web site. The main regulations } \\
\text { implementing the Consolidated Law are also available in English. The Consob's annual report in } \\
\text { Italian and an abridged version in English are posted on the Consob's Web site. } \\
\\
\text { As explained previously, BI has also a comprehensive publication program, covering BI's } \\
\text { responsibilities for securities market regulation. The BI's annual report in Italian and an abridged } \\
\text { version in English are posted on the BI's Web site. }\end{array}$ \\
\hline Assessment & Observed \\
\hline 7.4 .2 & $\begin{array}{l}\text { Senior financial agency officials should be ready to explain their institution's objective(s) and } \\
\text { performance to the public, and have a presumption in favor of releasing the text of their statements } \\
\text { to the public. }\end{array}$ \\
\hline Description & $\begin{array}{l}\text { The Senior officials of Consob and BI appear before Parliamentary Commissions and where } \\
\text { appropriate, take part in conferences. The texts of their statements are published on their respective } \\
\text { Web sites. }\end{array}$ \\
\hline Assessment & Observed \\
\hline 7.5 & $\begin{array}{l}\text { Texts of regulations and any other generally applicable directives and guidelines issued by } \\
\text { financial agencies should be readily available to the public. }\end{array}$ \\
\hline Description & $\begin{array}{l}\text { All the relevant regulations issued by Consob are available on Consob's Web site (including an } \\
\text { English version of the regulations implementing the Consolidated Law). } \\
\text { As far as securities markets and market infrastructures are concerned, the BI published a }\end{array}$ \\
\hline
\end{tabular}




\begin{tabular}{|c|c|}
\hline & $\begin{array}{l}\text { compendium with all the relevant regulations, available also on BI's Web site. The compendium is } \\
\text { regularly updated. The regulations and the other general measures issued by BI never enter into } \\
\text { force before their publication on the Gazzetta Ufficiale. }\end{array}$ \\
\hline Assessment & Observed \\
\hline 7.6 & $\begin{array}{l}\text { Where there are deposit insurance guarantees, policy-holder guarantees, and any other client } \\
\text { asset protection schemes, information on the nature and form of such protections, on the } \\
\text { operating procedures, on how the guarantee is financed, and on the performance of the } \\
\text { arrangement, should be publicly disclosed. }\end{array}$ \\
\hline Description & $\begin{array}{l}\text { Detailed rules on investor protection, operating procedures and financing are stated by legal } \\
\text { provisions. In particular, Articles } 59 \text { and } 60 \text { of the Consolidated Law on financial intermediation; } \\
\text { Decree of the Ministry of Treasury no.485 of } 14.11 .1997 \text { (Regulation on the organization and the } \\
\text { functioning of investors protection schemes), Operating Regulation of the Italian investor } \\
\text { protection scheme (Fondo nazionale di garanzia - FNG), bylaws of the FNG, are published in the } \\
\text { Gazzetta Ufficiale della Repubblica Italiana. } \\
\text { The above mentioned regulations and the list of the intermediaries that are members of the FNG } \\
\text { are available on the Web site of the Fondo (www.fondonazionaledigaranzia.it). } \\
\text { Information about the participation to the FNG and the conditions of investors protection have to } \\
\text { be provided to the clients by the financial intermediaries, pursuant to the Article } 2 \text { of the mentioned } \\
\text { ministerial Decree no.485 and Article 2(2) of the bylaws of the FNG. Furthermore, intermediaries } \\
\text { have to indicate their membership in the FNG in all their official documents and correspondence. }\end{array}$ \\
\hline Assessment & Observed \\
\hline 7.7 & $\begin{array}{l}\text { Where financial agencies oversee consumer protection arrangements (such as dispute } \\
\text { settlement processes), information on such arrangements should be publicly disclosed. }\end{array}$ \\
\hline Description & Consob and the BI do not oversee any securities market dispute settlement process \\
\hline Assessment & Not applicable \\
\hline \multicolumn{2}{|r|}{ VIII. ACCOUNTABILITY AND ASSURANCES OF INTEGRITY BY FINANCIAL AGENCIES } \\
\hline 8.1 & $\begin{array}{l}\text { Officials of financial agencies should be available to appear before a designated public } \\
\text { authority to report on the conduct of financial policies, explain the policy objective(s) of their } \\
\text { institution, describe their performance in pursuing their objective(s), and, as appropriate, } \\
\text { exchange views on the state of the financial system. }\end{array}$ \\
\hline Description & $\begin{array}{l}\text { Once a year, the Chairman of Consob officially presents the activity of the Commission to market } \\
\text { participants. The document submitted on that occasion summarizes the activities carried out and } \\
\text { highlights policy orientations for the following year. } \\
\text { The Chairman of Consob is required (see Article 1(12) of Law 216/74) to keep the Minister of } \\
\text { Economy and of Finance informed about major developments on the markets and the operation of } \\
\text { the Commission. The Minister is entitled to communicate his views to the Commission, informing } \\
\text { Parliament at the same time about these initiatives. More generally, the Minister can comment at } \\
\text { any time to Parliament about the activities of Consob. } \\
\text { The Minister can also ask Consob for confidential information, provided that this information is } \\
\text { needed in order to perform his statutory functions. This provision does not apply to the information } \\
\text { obtained through international cooperation (Article 4(4) of the Consolidated Law). } \\
\text { BI publicly reports on issues within the scope of its authority dealt with in parliamentary hearings } \\
\text { whenever the Parliament needs technical advice on subjects related to the functions of the Bank of } \\
\text { Italy and on other occasions. } \\
\text { Testimonies before Parliament are generally held by the Governor, the Director General and the } \\
\text { Deputies of the Director General, occasionally, by other senior officials. From } 1998 \text { till now } 11\end{array}$ \\
\hline
\end{tabular}




\begin{tabular}{|c|c|}
\hline & $\begin{array}{l}\text { parliamentary hearings on matters relating to the evolution of the financial and supervisory system } \\
\text { took place. }\end{array}$ \\
\hline Assessment & Observed \\
\hline 8.2 & $\begin{array}{l}\text { Where applicable, financial agencies should publicly disclose audited financial statements of } \\
\text { their operations on a pre-announced schedule. }\end{array}$ \\
\hline Description & $\begin{array}{l}\text { The budget and the financial statements of Consob, which give information on the use of resources } \\
\text { are published by Consob itself and can be consulted by any interested person (they are available on } \\
\text { Consob's web-site and on Consob's Official Journal). } \\
\text { A change in the use of resources with respect to that stated in the budget as approved by Consob } \\
\text { requests a modification of that budget. Any amendment to the budget is subject to a special internal } \\
\text { procedure and the decision adopted by Consob is published in the same ways the budget was } \\
\text { published. } \\
\text { BI publicly discloses its audited financial statement (balance sheet, income statement, notes to the } \\
\text { accounts) in its annual report, issued no later than five months after the end of its financial year. } \\
\text { BI's activities as securities regulator are not separated from its other activities. }\end{array}$ \\
\hline Assessment & Observed \\
\hline 8.2 .1 & $\begin{array}{l}\text { Financial statements, if any, should be audited by an independent auditor. Information on } \\
\text { accounting policies and any qualification to the statements should be an integral part of the } \\
\text { publicly disclosed financial statements. }\end{array}$ \\
\hline Description & $\begin{array}{l}\text { Consob manages its operating expenses autonomously on the basis of an annual budget approved } \\
\text { by the Commission. Its annual accounts (including internal accounting procedures) must be } \\
\text { approved by } 30 \text { April of each year and are audited by the Court of Auditors which is an } \\
\text { independent Court of law (Corte dei Conti). } \\
\text { Government accounting procedures are used. } \\
\\
\text { According to Article 27(1) of the statute of the European System of Central Banks and of the } \\
\text { European Central Bank, the accounts of the BI are audited by independent external auditors } \\
\text { recommended by the Governing Council of the European Central Bank and approved by the } \\
\text { European Council. The auditors are chosen among a restricted list of reliable and prominent } \\
\text { companies, who are members of the association of auditors. The mandate of the external auditor } \\
\text { has a duration of three years, and is renewable. Information on accounting policies and any } \\
\text { qualification to the statements are an integral part of BI's publicly disclosed financial statement. }\end{array}$ \\
\hline Assessment & Observed. \\
\hline 8.2 .2 & $\begin{array}{l}\text { Internal governance procedures necessary to ensure the integrity of operations, including internal } \\
\text { audit arrangements, should be publicly disclosed. }\end{array}$ \\
\hline Description & $\begin{array}{l}\text { Regulations governing the operation of Consob's (internal organization and procedures, } \\
\text { expenditures and personnel) are published on Consob's web site and on Consob's Official Journal. } \\
\text { As prescribed by law, Consob set up a special Internal Control Office. } \\
\\
\text { The Internal Inspectorate Department of BI drafts an Annual Report of its activity which contains } \\
\text { an overview of the most important internal organizational interventions, including significant data } \\
\text { on the activity carried out by it. Data on the auditing activity conducted by the Internal Inspectorate } \\
\text { are released on BI's Annual Report. }\end{array}$ \\
\hline Assessment & Observed \\
\hline 8.3 & $\begin{array}{l}\text { Where applicable, information on the operating expenses and revenues of financial agencies } \\
\text { should be publicly disclosed annually. }\end{array}$ \\
\hline Description & $\begin{array}{l}\text { The budget and audited financial statements of Consob are published on Consob's web-site and } \\
\text { Official Journal. They are supplemented by explanatory notes. Information about Consob's annual } \\
\text { income and expenditures is also provided in Consob's Annual report. } \\
\text { BI's activities as securities regulator are not separated from its other activities. }\end{array}$ \\
\hline
\end{tabular}




\begin{tabular}{|c|c|}
\hline Assessment & Observed \\
\hline 8.4 & $\begin{array}{l}\text { Standards for the conduct of personal financial affairs of officials and staff of financial } \\
\text { agencies and rules to prevent exploitation of conflicts of interest, including any general } \\
\text { fiduciary obligation, should be publicly disclosed. }\end{array}$ \\
\hline Description & 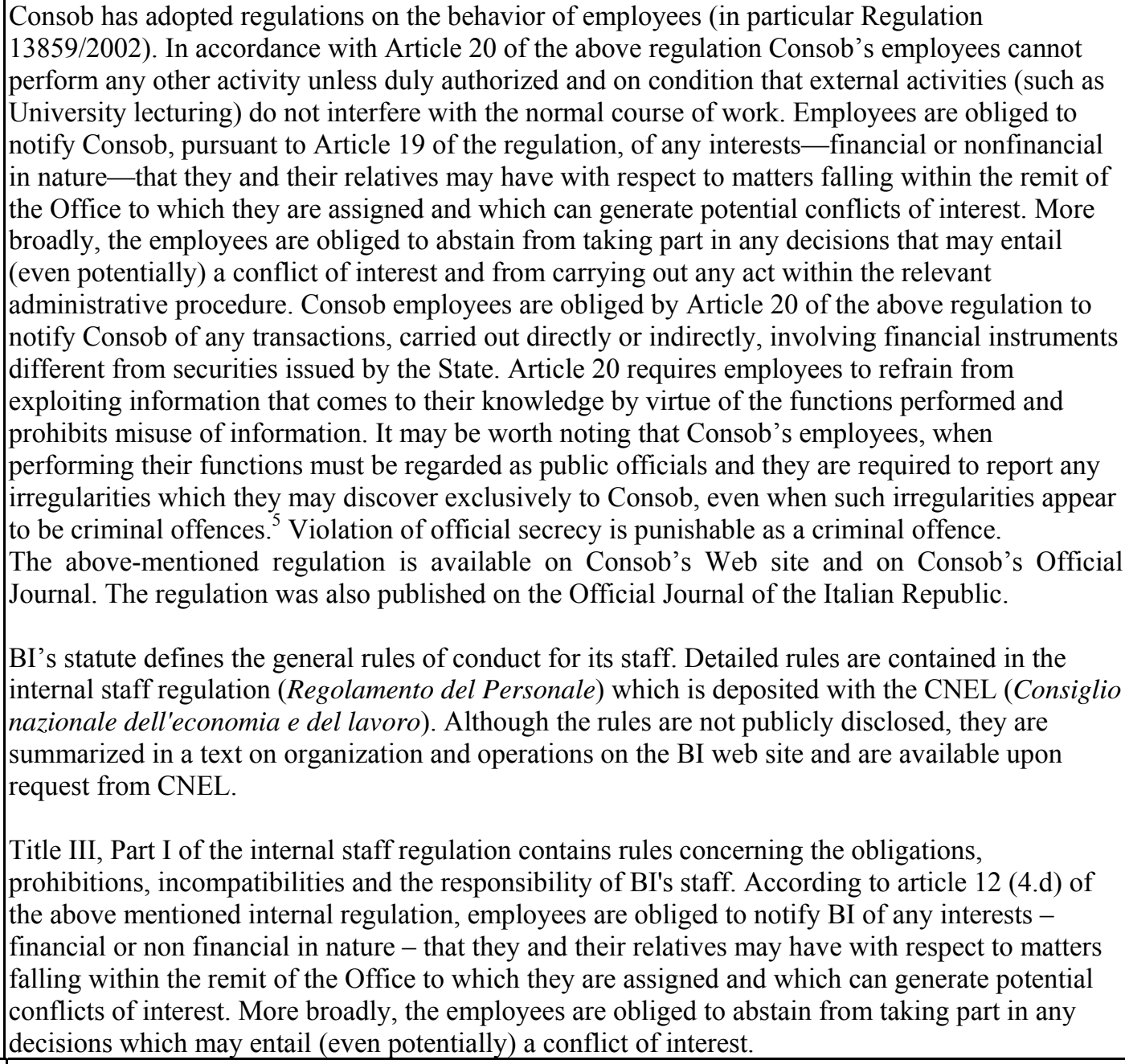 \\
\hline Assessment & Observed \\
\hline 8.4 .1 & $\begin{array}{l}\text { Information about legal protections for officials and staff of financial agencies in the conduct of } \\
\text { their official duties should be publicly disclosed. }\end{array}$ \\
\hline Description & $\begin{array}{l}\text { Articles } 22-30 \text { of the said Decree of the President of the Republic no.3/1957 which regulates the } \\
\text { civil servants are applicable to Consob staff (including members of the governing body). When } \\
\text { performing their functions, Consob's staff are considered public officials (Article } 4(11) \text { of the } \\
\text { Consolidated Law). Therefore, their liability may be engaged only in cases of serious/gross } \\
\text { negligence, fraud, deceit or willful wrong. The judicial authority is ultimately responsible to } \\
\text { sanction misbehavior and provide for compensation of damages suffered by persons injured by }\end{array}$ \\
\hline
\end{tabular}

\footnotetext{
${ }^{5}$ As a general rule, public officials are required to report directly to the public prosecutor when they are aware that a criminal offence has been committed. It will be up to the Consob to evaluate the information and if deemed necessary, to submit it to the public prosecutor.
} 


\begin{tabular}{|c|c|}
\hline & $\begin{array}{l}\text { Consob's staff. In addition, Consob can always adopt administrative measures in case of } \\
\text { misbehavior of its staff. } \\
\text { According to the law, BI staff are also performing their supervisory functions as public officials. } \\
\text { However, there is no legal protection offered to the BI and its officers against the possibility of } \\
\text { legal action resulting from measures adopted in good faith in the exercise of their supervisory } \\
\text { functions. As a matter of practice, the BI will pay the defense costs of a staff member subject to } \\
\text { such legal action where the staff member's actions were legitimate, and are responsible for the } \\
\text { payment of its own legal costs. }\end{array}$ \\
\hline ssessment & Not Applicable \\
\hline
\end{tabular}

\section{Table 2. Recommended Plan of Actions to Improve Observance of IMF's MFP Transparency Code Practices-Securities Regulation}

\begin{tabular}{|l|l|}
\hline \multicolumn{1}{|c|}{ Reference Practice } & \multicolumn{1}{|c|}{ Recommended Action } \\
\hline $\begin{array}{l}\text { V. Clarity of Roles, Responsibilities and } \\
\text { Objectives of Financial Agencies Responsible for } \\
\text { Financial Policies }\end{array}$ & \\
\hline $\begin{array}{l}5.1 .4 \text { Where applicable, the procedures for } \\
\text { appointment, terms of office, and any general } \\
\text { criteria for removal of the heads and members of the } \\
\text { governing bodies of financial agencies should be } \\
\text { publicly disclosed. }\end{array}$ & $\begin{array}{l}\text { Publicly disclose the applicability of Article 14.2 of the ESCB } \\
\text { Statute as regards the dismissal of the Governor and the general } \\
\text { criteria for removal of the heads and members of the governing } \\
\text { bodies in the absence of such provisions in the BI Statute. The } \\
\text { recently adopted Savings Law explicitly mentions Article 14.2 } \\
\text { of the ESCB Statute for the Governor's dismissal procedures. }\end{array}$ \\
\hline $\begin{array}{l}\text { VI. Open Process for Formulating and Reporting } \\
\text { Financial Policies }\end{array}$ & \\
\hline $\begin{array}{l}\text { 6.1.5 Where applicable, formal procedures for } \\
\text { information sharing and consultation between } \\
\text { financial agencies (including central banks), } \\
\text { domestic and international should be publicly } \\
\text { disclosed. }\end{array}$ & $\begin{array}{l}\text { Publicly disclose the details on protocols that define the } \\
\text { practical modalities of cooperation between domestic financial } \\
\text { agencies, and the actual procedures that are followed for } \\
\text { information sharing. Further to this recommendation, the MOU } \\
\text { governing the cooperations and exchange of information } \\
\text { between BI and Consob was made public on the Web sites of } \\
\text { the two institutions. }\end{array}$ \\
\hline & \\
\hline $\begin{array}{l}\text { VII. Public Availability of Information of } \\
\text { Financial Policies }\end{array}$ & \\
\hline & \\
\hline $\begin{array}{l}\text { VIII. Accountability and Assurances of Integrity } \\
\text { by Financial Agencies }\end{array}$ & \\
\hline
\end{tabular}




\section{Authorities' response to the assessment}

$\mathrm{BI}$ and Consob consider that the assessment recognizes a very high degree of compliance of the Italian supervisory system with the IMF Code of Good Practices on Transparency in Monetary and Financial Policies (MFPT Code) for securities supervision. ${ }^{6}$ The assessment shows that the objectives and responsibilities of the two supervisory authorities and the modalities of cooperation between them are clearly established in the 1998 Consolidated Law. The regulatory framework is publicly disclosed and explained.

\footnotetext{
${ }^{6}$ As regards the dismissal of the BI Governor see paragraph 175.
} 